КРИМІНАЛЬНЕ ПРАВО ТА КРИМІНОЛОГІЯ;

КРИМІНАЛЬНО-ВИКОНАВЧЕ ПРАВО

УДК 343.3

DOI https://doi.org/10.32844/2618-1258.2019.5-2.39

КИРИК I.C.

\title{
КЛЮЧОВІ ПРОБЛЕМИ НАЦІОНАЛЬНОӤ БЕЗПЕКИ ЯК НАСЛІДКИ НЕКОНТРОЛЬОВАНОЇ МІГРАЦІЇ НАСЕЛЕННЯ
}

У статті автор намагається проаналізувати складне та важливе питання національної безпеки країни, взаємозв'язку цього явища з сукупністю факторів внутрішньої та зовнішньої міграції населення. Аналізуються окремі теоретичні напрацювання вчених щодо природи руху індивідів в українському та світовому масштабах, можливості використання цих процесів у геополітичних цілях, територіальні диспропорції розміщення етнічних груп у межах країни тощо. Наголошено, що ризик посилення криміногенної ситуації внаслідок незаконної (неконтрольованої) міграції пов'язаний з залученням мігрантів до злочинних угруповань, побудованих за національною ознакою, а також спеціалізації на окремих видах злочинів. Визначено, що використання величезної кількості мігрантів як елемент політичного тиску, маніпуляцій та гібридної війни по відношенню до України проявляється в тому, що зайняті проблемами біженців європейські країни та США меншою мірою проявлятимуть активність та принциповість у питанні збереження санкцій щодо держави-агресора, відновлення територіальної цілісності України, повернення всіх окупованих територій під контроль офіційної легітимної влади. Зроблено висновок, що ключовими проблемами національної безпеки внаслідок неконтрольованої міграції населення $\epsilon: 1)$ використання мігруючого населення як фактору маніпуляцій, політичного тиску та гібридної війни у міжнародних відносинах; 2) цілеспрямований вплив владних структур Росії на витіснення з окупованих територій представників українського та кримськотатарського етносів, масове переселення в ці райони населення інших регіонів Росії з метою зменшення частки титульної нації та корінного народу Криму; 3) потенційні проблеми цивілізаційної ідентичності країни, її геополітичних, духовних, культурних пріоритетів та цінностей; 4) вибіркова концентрація мігрантів на певних територіях, низький рівень абсорбції до приймаючого суспільства; в окремих регіонах - поглинання мігрантами корінного населення в аспекті світоглядних цінностей та міждержавних відносин; 5) зростання злочинності, а саме залучення нелегальних мігрантів до протиправної діяльності, формування (посилення) злочинних угруповань, сформованих за національною ознакою; 6) соціально-економічні ризики функціонування держави; 7) екологічні ризики занесення рідкісних та небезпечних хвороб.

Ключові слова: неконтрольована міграція, нелегальна міграчія, начіональна безпека, ризики, переміщення населення.

In the article the author tries to analyze a complex and important issue of national security of the country, the relationship of this phenomenon with a set of factors of internal and external migration of the population. Some theoretical researches of scientists concerning the nature of the movement of individuals on the Ukrainian and world scale, the possibility of using these processes for geopolitical purposes, territorial disparities

(C) КИРИК І.С. - здобувач (Науково-дослідний інститут публічного права) 
of ethnic groups within the country, etc. are analyzed. It is emphasized that the risk of increased crime due to illegal (uncontrolled) migration is linked to the involvement of migrants in nationally-based criminal groups and specialization in particular types of crimes. It is determined that the use of large numbers of migrants as an element of political pressure, manipulation and hybrid war against Ukraine is manifested in the fact that, occupied with refugee problems, European countries and the USA will be less active and principled in maintaining sanctions against the aggressor state, the territorial integrity of Ukraine, the return of all occupied territories under the control of official legitimate authority. It is concluded that the key problems of national security as a consequence of uncontrolled migration of the population are: 1) the use of the migrating population as a factor of manipulation, political pressure and hybrid war in international relations; 2) purposeful influence of the Russian authorities on the expulsion of the representatives of the Ukrainian and Crimean Tatar ethnic groups from the occupied territories, mass resettlement to these regions of the population of other regions of Russia in order to reduce the share of the titular nation and the indigenous people of Crimea; 3 ) potential problems of a country's civilizational identity, its geopolitical, spiritual, cultural priorities and values; 4) selective concentration of migrants in certain territories, low level of absorption to the host society; in some regions, migrants' absorption of indigenous peoples in terms of worldview values and interstate relations; 5 ) increase in crime, namely the involvement of illegal migrants in illegal activities, the formation (strengthening) of criminal groups formed on a national basis; 6) socio-economic risks of the state; 7) ecological risks of rare and dangerous diseases.

Key words: uncontrolled migration, illegal migration, national security, risks, displacement.

Вступ. 3 розвитком державних утворень, еволюцією системи державного управління все більш очевидною стає для влади потреба контролювати міграційні процеси, корегувати інтенсивність та напрямки руху людських ресурсів. Адже в протилежному випадку з'являються серйозні загрози для національної безпеки будь-якої країни світу, ризики диспропорцій розвитку територій, послаблення економічного, політичного суверенітету, територіальної цілісності та незалежності держави. Отже, неконтрольована міграція населення є значною проблемою національної безпеки країни (групи країн, регіону), відповідно, чіткий, вичерпний, ефективний юридичний механізм розподілу адміністративно-владних повноважень (компетенцій) щодо регулювання цих процесів органами державної влади має велике значення.

Починаючи з 2014 року питання національної безпеки країни стало активним предметом наукових та публіцистичних пошуків в аспекті системного зв'язку з різними процесами в суспільстві. Водночас фахові наукові дослідження безпекового ризику для держави неконтрольованої міграції населення практично не здійснюються, що зумовлює актуальність цієї статті.

Мета статті - дослідження та виокремлення ключових проблем національної безпеки як наслідку неконтрольованої міграції населення.

Результати дослідження. На жаль, недоліки в системі державного управління фактично не дають змоги достовірно оцінити кількісні параметри та масштаби нелегальної імміграції та транзиту нелегалів в Україні. Хоча навіть експертні оцінки свідчать про те, що масштаби нелегальної міграції в Україні становлять пряму загрозу національній безпеці країни, створюють додаткове навантаження на державний бюджет, сприяють зростанню криміналізації, утворенню зон локалізації та контролю окремих національних злочинних груп, знижують асиміляційний потенціал корінного населення, сприяють загостренню соціальної та етнонаціональної напруги в регіонах $[1$, с. 2]. Довгий час українська влада досить таки умовно співвідносила питання неконтрольованої міграції та національної безпеки. Тобто порушення іноземцями правового режиму перебування в Україні, незаконний перетин кордону були лише одними з числа сотні інших складів адміністративних порушень, які фіксувалися та розглядалися в загальному порядку, без залучення безпекових структур. Лише після 2014 року влада нарешті все більш чітко починає розуміти, що населення може бути елементом гібридної війни, міграційні потоки можуть досить точно корегуватися в аспекті напрямків руху та його інтенсивності закордонними спецслужбами.

Б.П. Дмитрук та Н.М. Свєтлова під час вивчення питання мотивації, видів та наслідків світових міграційних процесів відмічають такі негативні фактори для країн виїзду, як втрата частини своєї робочої сили (до того ж у своїй більшості країну залишають найбільш кваліфіковані праців- 
ники); нівелювання так званого «ефекту віри» в розвиток економіки власної країни, що в кінцевому результаті призводить до зниження рівня інвестицій до неї; посилення позицій конкурентів у міжнародній торгівлі через відтік «мізків», неотримання певної частини національного доходу і податкових надходжень до бюджету [2, с. 24]. Додатково зазначимо, що для країн виїзду, зокрема України, глобальною проблемою стає питання старіння нації (адже виїжджають зазвичай молоді працездатні особи, часто з дітьми) та, відповідно, зростання дефіциту Пенсійного фонду. Що своєю чергою зумовлює потребу підняття пенсійного віку, введення додаткових податків, внаслідок чого з'являється перспектива соціальної напруженості та згортання (тінізації) бізнесу.

Американські дослідники К. Бреттелл та Д. Холіфілд у грунтовному дослідженні, присвяченому проблематиці міжнародних міграцій, виокремлюють три головних теоретичних блоки цього питання. По-перше, це проблеми національного суверенітету та контролю за переміщеннями; по-друге, принципи національної безпеки; по-третє, це проблеми інкорпорування мігрантів в середовище приймаючого соціуму [3, с. 99]. На нашу думку, зазначені теоретичні блоки досить вдало відображають поточні реалії впливу міграційних процесів на світовий лад, громадсько-політичні, соціальні, економічні трансформації, що відбуваються не лише в окремих державах, а цілих регіонах та континентах. Що знову ж таки підкреслює серйозний ризик неконтрольованої міграції населення як проблеми національної безпеки кожної країни, в тому числі і нашої держави.

Зазначений ризик має багато різних аспектів, напрямів проявів, на чому зупинимося детальніше. Як справедливо відмічає соціальний психолог О. Покальчук, у сучасних війнах, де фізичне знищення ворога вже не є пріоритетом, а захоплення території - лише інструмент вирішення власних внутрішніх проблем, найбільш грізною зброєю є людські маси. Якщо раніше ворог силоміць гнав цивільне населення захоплених територій поперед себе на мінні поля, щоб створити безпечний коридор для прориву, то тепер, створюючи надлишковий тиск страху й горя в одному місці та ілюзію легкого й безпечного благополуччя в іншому, мільйони людей кидають у такі економіко-психологічні наступи, рівних яким історія ще не знала [4]. Ця закономірність була зауважена в контексті екскалації Росією напруження на Близькому Сході та, відповідно, появи сотні тисяч біженців у Свропі, що зумовило найбільшу соціально-політичну кризу з часів закінчення другої світової війни.

Використання величезної кількості мігрантів як елемент політичного тиску, маніпуляцій та гібридної війни по відношенню до України проявляється в тому, що зайняті проблемами біженців європейські країни та США меншою мірою проявлятимуть активність та принциповість у питанні збереження санкцій щодо держави-агресора, відновлення територіальної цілісності України, повернення всіх окупованих територій під контроль офіційної легітимної влади. Як приклад маніпуляцій питанням вимушених переселенців на сході України можуть слугувати повідомлення Посольства Російської Федерації в Лондоні в лютому 2018 року про те, що із 2014 року 1,7 мільйона українців (3,8\% від загальної кількості населення) шукали притулку в Росії. Тоді як Федеральна служба статистики Росії повідомляє про інші цифри - 32014 по 2017 роки статус біженця отримало всього 693 людини; чисельність вимушених переселенців з України становить 762 людини [5]. Так само не гребують маніпуляціями і західні сусіди України. Зокрема, Польща та Словаччина, відмовляючись приймати біженців в рамках розподільчих квот в СС, посилалися на нічим не підтверджені дані про «сотні тисяч» українських біженців, які через військові дії прибули до цих країн.

Не менш вагомим ризиком неконтрольованої міграції як загрози національної безпеки $\epsilon$ потенційні проблеми цивілізаційної ідентичності країни, іiі геополітичних, духовних, культурних пріоритетів та цінностей. Важливість цього ризику для України полягає в тому, що євразійський (російський) проект глобалізації розглядає Україну як сферу власного регіонального впливу та, відповідно, позиціонує як адресат експорту свого способу життя та світоглядних цінностей $[6$, с. 31]. 3 огляду на безвізовий режим між Україною та Росією, слабкість режиму прикордонного контролю цей ризик найбільш яскраво характеризує саме неконтрольовану міграцію як цілком законне переміщення громадян інших держав у межах України, що перебувають тут на правових підставах.

Вибіркова концентрація цих мігрантів на територіях, які Росія вважає зоною свого пріоритетного впливу, вже зумовила колосальні територіальні та людські втрати починаючи з 2014 року. Цю ситуацію яскраво демонструє інтерв'ю голови Верховної Ради України та тимчасово виконуючого обов'язки Президента в лютому - травні 2014 року О.В. Турчинова, який заявив, що давав наказ військовим застосовувати зброю, але наказ був просто проігнорований. Місцеві командири військових підрозділів відверто доповідали головнокомандуючому, «що у них більше ніж поло- 
вина бійців - місцеві, вони не готові воювати... Не готові не те, що захищати частини, але навіть робити вигляд, що захищають» [7]. На жаль, подібні політично-військові катастрофи все одно не стали для української влади останнім аргументом першочергової потреби аналізу національного розселення України та оцінки можливостей антидержавних проявів, зумовлених ними.

Також активне переселення росіян в Україну (передусім в індустріальні райони півдня та сходу України), в сукупності з пасивною інформаційною політикою держави 3 консолідації нації, байдужістю населення до власної історії та ідентичності, зумовило надзвичайно низький рівень абсорбції мігрантів до приймаючого суспільства. Навіть більше, швидше мігранти поглинули корінне населення, нав'язали свої культурно-світоглядні цінності, ніж навпаки. Наприклад, за даними переписів населення 1989 та 2001 років, чисельність етнічних українців, що вважають рідною українську мову, зменшилася з 87,8\% до 85,2\%; з відповідним зростанням частки тих, які визнають рідною російську мову. Отже, з погляду міграційної активності подібне явище $\epsilon$ додатковим аспектом глобалізаційних викликів, зумовлює нагальну потребу врахування цих тенденцій, можливих соціокультурологічних наслідків міграційних процесів під час здійснення загальнодержавної та регіональної міграційної політики $[8$, с. 72]. Як би це парадоксально не звучало, але основний ризик культури, цивілізаційної ідентичності України зумовлений якраз не різницею в культурі прибулого та місцевого населення, а їх значним ступенем подібності внаслідок асиміляційної політики СРСР. Відтак багатьом українським громадянам цілком комфортно перебувати в російському інформаційному та культурному просторі, при цьому українську ідентичність вони починають сприймати як чуже, стороннє по відношенню до себе явище.

Досить суперечливим ризиком неконтрольованої міграції (який має як своїх прибічників, так і противників) $€$ проблема зростання злочинності, а саме залучення нелегальних мігрантів до протиправної діяльності. За визначенням В.Ф. Левковського, кримінальна міграція - це соціальне, відносно масове, суспільно небезпечне явище, що виявляється в територіальному переміщенні осіб з метою вчинення злочинів, а також переміщенні кримінальних технологій через кордони тих чи інших територій [9, с. 93]. Традиційно ризик посилення криміногенної ситуації внаслідок незаконної (неконтрольованої) міграції пов'язаний з залученням мігрантів до злочинних угруповань, побудованих за національною ознакою, а також спеціалізації на окремих видах злочинів. Наприклад, свого часу під час активної боротьби зі злочинністю в Грузії лідери кримінальних угруповань цієї країни переїхали в Україну, звідки керували закордонною протиправною діяльністю, а також брали участь у перерозподілі сфер впливу у вітчизняному злочинному світі.

Складним для оцінки та аналізу є соціально-економічний ризик неконтрольованої міграції. Попри очевидний негативний вплив на популяцію, відтворення населення, наповнення бюджетних фондів за рахунок зниження кількості працездатного населення, справедливо оцінити цей ризик практично неможливо. Адже можна лише приблизно гадати про кількість трудових мігрантів з України закордоном, а також чисельність, віковий склад поточного населення держави. Справді, досить таки умовними є дані Державної служби статистики України, яка інформує, що станом на 01 червня 2019 р. наявне населення держави становить 42,030832 млн чоловік [10]. У цьому ракурсі неспівставними $є$ прогнози різних експертів щодо демографічного потенціалу України. В будь-якому випадку стрімка депопуляція, в тому числі через виїзд населення України за кордон, є серйозним викликом національній безпеці та економіці країни.

Висновки. Виокремлюємо такі ключові проблеми національної безпеки як наслідки неконтрольованої міграції населення: 1) використання мігруючого населення як фактору маніпуляцій, політичного тиску та гібридної війни у міжнародних відносинах; 2) цілеспрямований вплив владних структуру Росії на витіснення з окупованих територій представників українського та кримськотатарського етносів, масове переселення в ці райони населення інших регіонів Росії 3 метою зменшення частки титульної нації та корінного народу Криму; 3) потенційні проблеми цивілізаційної ідентичності країни, іії геополітичних, духовних, культурних пріоритетів та цінностей; 4) вибіркова концентрація мігрантів на певних територіях, низький рівень абсорбції до приймаючого суспільства; в окремих регіонах - поглинання мігрантами корінного населення в аспекті світоглядних цінностей та міждержавних відносин; 5) зростання злочинності, а саме залучення нелегальних мігрантів до протиправної діяльності, формування (посилення) злочинних угруповань, сформованих за національною ознакою; 6) соціально-економічні ризики функціонування держави (негативний вплив на популяцію, відтворення населення тенденції виїзду українців за кордон та старіння нації; проблема наповнення бюджетних фондів за рахунок зниження кількості працездатного населення; необхідність підняття пенсійного віку, податків з метою подолання дефіциту Пенсійного фонду); 7) екологічні ризики занесення рідкісних та небезпечних 
хвороб, епідемій з країн Африки та Південної Азії, де панує антисанітарія та поширені специфічні хвороби, від яких населення України не має набутого імунітету та діагностування, лікування яких є досить складним).

\title{
Список використаних джерел:
}

1. Хомич Л.В. Нелегальна імміграція на Півдні України: стан, потенційні загрози і наслідки. URL: old.niss.gov.ua/Monitor/januar2009/9.htm.

2. Дмитрук Б.П., Свєтлова Н.М. Світові міграційні процеси: мотивація, види й наслідки для країн виїзду та приймаючих країн. Вісник Східноєвропейського університету економіки $i$ менеджменту. Серія: Економіка і менеджмент. 2016. № 1. С. 18-27.

3. Brettell Caroline B., Hollifield James F. Migration Theory: Talking Across Discipline. New York. 2007. 304 p. URL: https://estvitalesydemografia.files.wordpress.com/2013/04/introduccic3b3nmigration-theory-talking-across-disciplines.pdf.

4. Покальчук О. Зброя Горя. Дзеркало тижня (електронне видання). URL: https://dt.ua/socium/zbroya-gorya-_.html.

5. Фейк: 32014 року 1,7 мільйона українців попросили притулку в Pociï. URL: https://www.stopfake.org/uk/fejk-z-2014-roku-1-7-miljona-ukrayintsiv-poprosyly-prytulku-v-rosiyi/.

6. Українське суспільство: міграційний вимір : нац. доповідь / Інститут демографії та соціальних досліджень ім. М. В. Птухи НАН України. Київ, 2018. 396 с.

7. Турчинов давав наказ стріляти в Криму, але військові його не послухали. URL: http://ukr.lb.ua/news/2014/06/27/271213_turchinov_daval_prikaz_strelyat.html.

8. Наслідки міграційних процесів: нові виклики та можливості для регіонів / НАН України, ДУ «Інститут регіональних досліджень імені М.I. Долішнього» ; наук. ред. У.Я. Садова. Львів, 2015. 252 с.

9. Левковський В.Ф. Нелегальна міграція - загроза національній безпеці України. Боротьба з організованою злочинністю і корупиією (теорія і практика). 2007. Вип. 16. С. 89-98.

10. Чисельність населення (за оцінкою) на 1 червня 2019 року та середня чисельність у січні-травні 2019 року. Дані Державної служби статистики України. URL: http://www.ukrstat.gov.ua/ operativ/operativ2019/ds/kn/kn_u/kn0519_u.html.

УДК 343.01

DOI https://doi.org/10.32844/2618-1258.2019.5-2.40

МАРЧУК Р.М.

\section{ОСНОВНІ НАПРЯМИ ОПТИМІЗАЦІЇ ОРГАНІЗАЦИЙНОЇ СТРУКТУРИ ДЕРЖАВНОГО БЮРО РОЗСЛІДУВАНЬ}

\begin{abstract}
Формується авторське визначення організаційної структури Державного бюро розслідувань. Визначаються та детально аналізуються такі ознаки структури Державного бюро розслідувань, як нормативна визначеність, стійка впорядкованість, ієрархічність, спрямованість на досягнення стратегічних цілей діяльності, спеціалізація. У межах характеристики зазначених ознак розглядаються недоліки організаційної структури Державного бюро розслідувань, а також обгрунтовуються найбільш перспективні напрями ії оптимізації. 3'ясовано, що в найбільш загальному розумінні спеціалізація органів і підрозділів Державного бюро розслідувань проявляється в логічному і науково обгрунтованому розподілі основних завдань і функцій, які покладаються на Державне бюро розслідувань, між його основними структурними підрозділами. Такі підрозділи, з одного боку, діють самостійно, оскільки спеціалізація передбачає насамперед їх функціональну замкнутість. Це дозволяє максимально конкретизувати виконання окремих завдань і функцій, які покладаються на Державне бюро розслідувань. Однак з іншого боку така самостійність
\end{abstract}

(C) МАРЧУК Р.М. - здобувач (Науково-дослідний інститут публічного права) 